\title{
SCREENING GALUR TETUA JAGUNG (Zea mays L.) MUTAN GENERASI M4 BERDASARKAN ANALISIS TOPCROSS DI ARJASARI, JAWA BARAT
}

\author{
Screening of Parental Lines of Maize (Zea mays) \\ mutant M4 Generation based on Analysis of Topcross \\ in Arjasari, West Java \\ Jajang Supriatna ${ }^{1}$ dan Dedi Ruswandi ${ }^{2}$ \\ ${ }^{1}$ Program Studi Agroteknologi Fakultas Pertanian Universitas \\ Garut \\ ${ }^{2}$ Laboratorium Pemuliaan Tanaman, Fakultas Pertanian \\ Universitas Padjadjaran \\ E-mail : jajang.supriatna60@yahoo.co.id
}

\begin{abstract}
Abstrak
Informasi mengenai nilai Daya Gabung Umum (DGU) dan High-Parent Heterosis (HPH) diperlukan dalam kegiatan seleksi untuk menentukan sumber genetik potensial dalam pengembangan kultivar unggul baru. Topcross merupakan salah satu metode yang efektif digunakan karena mampu mengestimasi nilai DGU serta data hasil pengamatan tetua beserta progeninya dapat digunakan untuk mengestimasi nilai $\mathrm{HPH}$. Tujuan penelitian ini yaitu untuk mendapatkan galur inbred superior berdasarkan nilai DGU dan HPH pada beberapa karakter komponen hasil. Penelitian telah dilaksanakan di Kecamatan Arjasari, Jawa Barat pada bulan Maret-Juli 2013. Materi genetik yang diteliti terdiri dari 46 galur $\mathrm{M}_{4} \mathrm{DR}$ yang diuji berdasarkan metode topcross dengan menyertakan DR8 sebagai tetua tester. Hasil penelitian menunjukkan bahwa terdapat 12 galur yang memiliki nilai DGU tinggi. Terseleksi 7 pasangan persilangan berdasarkan nilai HPH. Galur $\mathrm{M}_{4} \mathrm{DR}$ 4.8.8 dan $\mathrm{M}_{4} \mathrm{DR}$ 18.4.1 memiliki nilai daya gabung yang tinggi pada beberapa karakter komponen hasil sehingga berpotensi untuk dikembangkan sebagai tetua dalam perakitan kultivar jagung berdaya hasil tinggi.
\end{abstract}

Kata Kunci : jagung, galur inbred, topcross, komponen hasil 


\begin{abstract}
Informationabout General Combining Ability (GCA) and High-Parent Heterosis (HPH) is required in the selection, to define the potential genetic resources in the development of new superior cultivars. Topcross analysis is one most prominent method with its effectivity on estimating GCA value as well as the reliability of its progeny on estimating $\mathrm{HPH}$ value. The objective of this research done at Arjasari, West Java, from March until July 2013 was to obtain superior inbreds based on GCA and HPH value in some yield component characters. The genetic material researched is consisted of $46 M_{4} D R$ lines tested based on topcross method with $D R 8$ as the parent tester. The results indicated that 12 lines had showed high GCA value. Seven pairs of crosses was selected based on HPH value. $M_{4} D R$ 4.8.8 and $M_{4} D R$ 18.4.1 lines had high GCA value on some yield component characters, so that, those inbreds are potential to be developed as parents in assembling new high-yielding maize cultivars.
\end{abstract}

Keywords : corn, inbred line, topcross, yield

\section{PENDAHULUAN}

Galur inbred (inbred line) merupakan individu tanaman menyerbuk silang yang memiliki konstitusi genetik homozigot atau mendekati homozigot yang dikembangkan melalui silang dalam (selfing) beberapa generasi (Vasal et al., 1999). Galur inbred memiliki peranan penting dalam pengembangan kultivar unggul terutama dalam perakitan hibrida tanaman menyerbuk silang. Konsep dasar pemanfaatan galur inbred pertama kali diperkenalkan oleh Shull (1908) yang menemukan bahwa hasil dari silang dalam tanaman jagung mengakibatkan terjadinya depresi inbreeding yaitu penurunan sifat dibandingkan dengan tetuanya persilangan dua tetua homozigot menghasilkan generasi $F_{1}$ yang sangat vigor.

Kegiatan seleksi galur inbred pada umumnya diarahkan untuk mencari kombinasi tetua yang dapat memberikan ekspresi maksimum sifat-sifat agronomi yang diinginkan pada generasi keturunannya. Produksi galur inbred dengan cara silang dalam selama 
beberapa generasi dapat menghasilkan variabilitas genetik yang diperlukan dalam kegiatan seleksi. Masalah yang harus dihadapi dalam menyeleksi galur inbred yaitu banyaknya galur murni yang dihasilkan sehingga diperlukan metode yang efisien dan akurat dalam pengujiannya (Hallauer dan Miranda, 1988). Keputusan yang diambil harus seideal mungkin, karena proses seleksi yang tidak efektif bisa menyebabkan hilangnya potensi-potensi genetik yang justru dibutuhkan dalam pengembangan genotipe unggul.

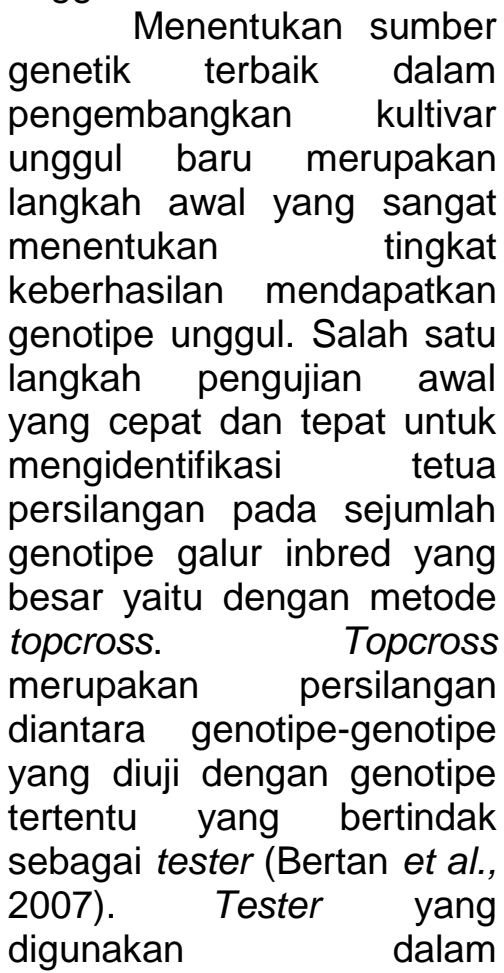

persilangan adalah sama untuk setiap galur pengujian sehingga memberikan sumbangan gen yang sama dari tester pada setiap keturunannya. Dasar dari pengujiannya yaitu, perbedaan nilai diantara keturunan yang merupakan perbedaan genetik tetua yang akan diseleksi. Metode topcross memungkinkan untuk mengevalusi kemampuan Daya Gabung Umum (DGU) tetua persilangan dan HighParent Heterosis (HPH) pada generasi hasil persilangan sebagai salah satu parameter dalam menentukan tetua superior dalam pengembangan kultivar unggul baru. Menurut Doerksen et al., (2003), bahwa parameter tersebut dapat digunakan untuk menyeleksi galur-galur unggul sebagai tetua potensial hibrida jagung superior. DGU merupakan ukuran dari kemampuan rata-rata suatu genotipe dalam menghasilkan keturunan jika disilangkan dengan genotipe lain (Allard, 1960). Menurut Sprague dan Tatum (1942), nilai DGU dapat menunjukkan aksi gen dan kontribusi tetua dalam meningkatkan karakter pada hasil keturunannya sehingga dapat digunakan sebagai evaluasi dalam menyeleksi tetua, sedangkan nilai HPH 
menunjukkan peningkatan nilai suatu karakter pada generasi $F_{1}$ dibandingkan dengan tetuanya dengan nilai tertinggi (Fehr, 1987).

Tujuan

dari

penelitian ini yaitu untuk mengestimasi nilai DGU galur-galur $\mathrm{M}_{4} \mathrm{DR}$ dan mengestimasi nilai $\mathrm{HPH}$ dari setiap pasangan persilangan hibrida topcross berdasarkan karakter komponen hasil. Informasi dari hasil penelitian ini akan sangat berguna untuk menentukan galur potensial untuk pengembangkan kultivar unggul baru yang memiliki hasil tinggi yang dapat dirilis sebagai benih unggul jagung bagi petani.

\section{METODOLOGI \\ Mater Genetik}

digunakan

Materi genetik yang

pembentukan dalam hibrida topcross adalah 46 galur $\mathrm{M}_{4} \mathrm{DR}$ and DR8 yang merupakan galur tester. Galur-galur tersebut merupakan galur potensial hasil pengembangan Laboratorium Pemuliaan Tanaman Fakultas

Pertanian Universitas

Padjadjaran. Galur $\mathrm{M}_{4} \mathrm{DR}$ dihasilkan dari hasil mutasi galur DR dengan menggunakan sinar gamma yang kemudian disilang dalam (selfing) dan diseleksi berdasarkan seleksi pedigree sebanyak 4 generasi. Galur DR merupakan merupakan galur elit yang dikembangkan dari hasil persilangan Downy Mildew Resistant Maize (DMR Maize) dan Quality Protein Maize (QPM). Pembentukan populasi $F_{1}$ hibrida yaitu dengan menyilangkan $46 \quad \mathrm{M}_{4} \mathrm{DR}$ dengan DR8. Persilangan menghasilkan 46 kombinasi persilangan yang merupakan materi untuk evaluasi daya gabung dan heterosis.

\section{Desain Percobaan}

Penelitian

dilaksanakan di Sanggar Penelitian Latihan dan Pengembangan Pertanian (SPLPP) Arjasari Fakultas Pertanian Universitas Padjadjaran pada bulan Maret-Juli 2013. Desain percobaan yang digunakan yaitu Rancangan Acak Kelompok dengan 47 perlakuan (46 galur $\mathrm{M}_{4} \mathrm{DR}$ dan DR8) dengan 2 ulangan. Karakter-karakter yang diamati dalam penelitian ini diantaranya panjang tongkol (cm), diameter tongkol $(\mathrm{cm})$, bobot 1000 biji (g) dam bobot biji per tanaman $(\mathrm{g})$. 
Estimasi Nilai Daya

Gabung Umum (DGU)

Daya gabung umum dihitung menurut Hallauer dan Miranda (1988), yaitu:

$$
d g_{i}=\frac{\bar{x} l-\bar{x}}{\bar{x}} \times 100 \%
$$

Keterangan

$$
\begin{aligned}
& d g_{i} \quad \text { : daya gabung galur } \\
& \text { ke i } \\
& \bar{x} \text { : rata-rata } \\
& \text { pengamatan } \\
& \text { hibrida topcross ke } \\
& \bar{x}: \begin{array}{l}
\text { rata-rata } \\
\text { pengamatan }
\end{array} \\
& \text { semua hibrida } \\
& \text { topcross }
\end{aligned}
$$

Uji signifikansi DGU dilakukan dengan Uji-t menurut Singh dan Chaundary (1979), yaitu:

$$
t=\frac{\left|\overline{x_{1}}-\overline{x_{2}}\right|}{\sqrt{\frac{S_{1}{ }^{2}}{n_{1}}+\frac{s_{2}{ }^{2}}{n_{2}}}}
$$

Keterangan

$t$ : nilai $\mathrm{t}$ galur murni ke-i

$\overline{x_{1}}$ : rata-rata DGU galur murni ke-i

$\overline{x_{2}} \quad$ : rata-rata $\mathrm{DGU}$ semua galur murni

$S_{1}{ }^{2}$ : varians DGU galur murni ke-i

$S_{2}{ }^{2}$ : varians rata-rata DGU

$n$ : banyaknya objek
Semua nilai $\mathrm{t}$ hitung yang lebih besar dari $t$ tabel (thit>T0,05) menunjukkan nilai daya gabung umum untuk galur yang diuji signifikan.

\section{Estimasi Nilai High-Parent Heterosis (HPH)}

Nilai $\mathrm{HPH}$ yang dihitung berdasarkan penampilan tetua terbaik, dengan rumus berdasarkan Fehr (1987), yaitu:

$\mathrm{HPH}(\%)=\left[\frac{\overline{F_{1}}-\overline{H P}}{\overline{H P}}\right] \times 100 \%$

Dimana :

$\mathrm{HPH}(\%) \quad$ : Nilai HPH

$\mathrm{F}_{1} \quad$ : Nilai rata-

rata dari $F_{1}$

HP

terbaik

HASIL

PEMBAHASAN

DAN

\section{Nilai Daya GabungUmum (DGU)}

Hasil analisis ragam karakter komponen hasil galur-galur yang diuji dapat dilihat pada Tabel 1. Hasil menunjukkan bahwa genotipe berpengaruh nyata terhadap semua karakter yang diamati. Pengaruh nyata genotipe terhadap semua karakter yang dianalisis menunjukkan bahwa galur-galur $\mathrm{M}_{4} \mathrm{DR}$ yang digunakan dalam 
penelitian ini memiliki keragaman genetik yang tinggi. Keragaman genetik pada galur $\mathrm{M}_{4} \mathrm{DR}$ sebelumnya dilaporkan oleh Sucipto dkk. (2013), berdasarkan analisis UPGMA coefficient menghasilkan Euclidean yang cluster-cluster galur berdasarkan jarak genetik diantara galur-galur $\mathrm{M}_{4} \mathrm{DR}$. Sumber variasi tetua vs persilangan digunakan sebagai pertimbangan penghitungan nilai daya gabung. Hasil menunjukkan bahwa tetua vs persilangan menunjukkan pengaruh nyata terhadap semua karakter. Menurut Beck et al., (1990), bahwa penghitungan nilai daya gabung dapat dilanjutkan apabila terdapat pengaruh nyata tetua vs persilangan pada karakter yang diamati.

Tabel 1. Analisis Ragam Karakter Komponen Hasil.

\begin{tabular}{|c|c|c|c|c|c|c|}
\hline \multirow{2}{*}{$\begin{array}{c}\text { Sumber } \\
\text { ragam }\end{array}$} & \multirow[t]{2}{*}{$\mathrm{dB}$} & \multicolumn{4}{|c|}{ Mean Sauares } & \multirow{2}{*}{$\begin{array}{c}F \text { tab } \\
0,05\end{array}$} \\
\hline & & PT & DT & B 1000 & BBT & \\
\hline Ulangan & 1 & $8,87^{\star}$ & $24,04^{*}$ & $18,86^{*}$ & 2,67 & 4,05 \\
\hline Genotipe & 46 & $1,86^{*}$ & $2,70^{*}$ & $1,67^{*}$ & $1,64^{*}$ & 1,63 \\
\hline Persilangan & 45 & $1,46^{*}$ & $2,21^{*}$ & 0,99 & $1,65^{*}$ & 1,63 \\
\hline $\begin{array}{l}\text { Tetua vs } \\
\text { Persilangan }\end{array}$ & 1 & $4,20^{*}$ & $21,78^{*}$ & $40,87^{*}$ & $4,79^{*}$ & 4,05 \\
\hline $\begin{array}{l}\text { Galat } \\
\mathrm{KV}\end{array}$ & 46 & 9,77 & 5,51 & 22,10 & 17,15 & \\
\hline
\end{tabular}

Keterangan : $\mathrm{db}=$ Derajat bebas ; KV $=$ Koefisien Variasi

PT $=$ Panjang tongkol $(\mathrm{cm}) ; \mathrm{DT}=$ Diameter tongkol $(\mathrm{cm}) ; \mathrm{B} 1000$ = Bobot 1000 biji ; BBT = Bobot biji per tanaman (g).

* signifikan berdasarkan Uji t pada taraf $5 \%$

Nilai daya gabung umum (DGU) dari masingmasing genotipe untuk setiap karakter dapat dilihat pada lampiran 1. Hasil menunjukkan bahwa nilai beragam pada setiap galur yang diuji. Nilai positif menunjukkan bahwa suatu galur mampu menghasilkan suatu progeni dengan nilai rata-rata karakter lebih tinggi dibandingkan dengan tetuanya ketika disilangkan dengan tester, sebaliknya jika nilai negatif artinya bahwa suatu galur progeni yang memiliki karakter lebih rendah dibandingkan dengan tetuanya ketika disilangkan dengan tester.

Pada penelitian ini, nilai positif dipilih dengan tujuan untuk mendapatkan tetua potensial yang mampu menghasilkan progeni 
dengan potensi hasil yang lebih tinggi. Berdasarkan hasil analisis pada karakter komponen hasil, terpilih 12 Galur yang menunjukkan DGU tinggi. Daftar galur terpilih berserta nilai DGU dan nilai rata-rata karakter ditampilkan pada Tabel 2. Galur-galur terpilih diantaranya 4 Galur berdasarkan karakter panjang tongkol, 5 galur terpilin berdasarkan Diameter Tongkol, 6 Galur berdasarkan bobot 1000 biji, 4 galur berdasarkan bobot biji per tanaman.

Tabel 2. Galur-Galur Terpilih Berdasarkan Nilai DGU Tertinggi Pada Beberapa Karakter Komponen Hasil.

\begin{tabular}{|c|c|c|c|c|}
\hline No. & PT & DT & B 1000 & BBT \\
\hline$\overline{11}$ & $\begin{array}{c}\text { Galur } \mathrm{M}_{4} \mathrm{DR} \\
18.4 .1 \\
\text { DGU 2.3* } \\
\text { Rata-rata } \\
20,04 \mathrm{~cm}\end{array}$ & $\begin{array}{c}\text { Galur } \mathrm{M}_{4} \mathrm{DR} \\
16.1 .1 \\
\text { DGU 5.07*} \\
\text { Rata-rata } \\
18,68 \mathrm{~mm}\end{array}$ & $\begin{array}{c}\text { Galur } \mathrm{M}_{4} \mathrm{DR} \\
3.1 .2 \\
\text { DGU 59.50* } \\
\text { Rata-rata } \\
293,00 \mathrm{~g}\end{array}$ & $\begin{array}{c}\text { Galur } \mathrm{M}_{4} \mathrm{DR} \\
18.4 .1 \\
\text { DGU 30.43*} \\
\text { Rata-rata } \\
223,67 \mathrm{~g}\end{array}$ \\
\hline 2 & $\begin{array}{c}\text { Galur } \mathrm{M}_{4} \mathrm{DR} \\
5.5 .1 \\
\text { DGU 1.84* } \\
\text { Rata-rata } \\
18,34 \mathrm{~cm} \\
\end{array}$ & $\begin{array}{c}\text { Galur } \mathrm{M}_{4} \mathrm{DR} \\
12.3 .2 \\
\text { DGU } 3.27^{*} \\
\text { Rata-rata } \\
17,93 \mathrm{~mm}\end{array}$ & $\begin{array}{c}\text { Galur } \mathrm{M}_{4} \mathrm{DR} \\
16.1 .1 \\
\text { DGU 45.63* } \\
\text { Rata-rata } \\
300,00 \mathrm{~g}\end{array}$ & $\begin{array}{c}\text { Galur } \mathrm{M}_{4} \mathrm{DR} \\
4.8 .8 \\
\text { DGU 21.93* } \\
\text { Rata-rata } \\
193,33 \mathrm{~g} \\
\end{array}$ \\
\hline 3 & $\begin{array}{c}\text { Galur } \mathrm{M}_{4} \mathrm{DR} \\
4.8 .8 \\
\text { DGU 1.83* } \\
\text { Rata-rata } \\
18,31 \mathrm{~cm}\end{array}$ & $\begin{array}{c}\text { Galur } \mathrm{M}_{4} \mathrm{DR} \\
4.8 .8 \\
\text { DGU 2.28*} \\
\text { Rata-rata } \\
17,17 \mathrm{~mm}\end{array}$ & $\begin{array}{c}\text { Galur } \mathrm{M}_{4} \mathrm{DR} \\
18.4 .1 \\
\text { DGU 40.06* } \\
\text { Rata-rata } \\
250,00 \mathrm{~g}\end{array}$ & $\begin{array}{c}\text { Galur } \mathrm{M}_{4} \mathrm{DR} \\
9.1 .3 \\
\text { DGU 20.38*} \\
\text { Rata-rata } \\
180,67 \mathrm{~g}\end{array}$ \\
\hline 4 & $\begin{array}{c}\text { Galur } \mathrm{M}_{4} \mathrm{DR} \\
8.5 .2 \\
\text { DGU 1.71* } \\
\text { Rata-rata } \\
18,30 \mathrm{~cm} \\
\end{array}$ & $\begin{array}{c}\text { Galur } \mathrm{M}_{4} \mathrm{DR} \\
1.1 .3 \\
\text { DGU 2.13*} \\
\text { Rata-rata } \\
\text { 18,12 mm }\end{array}$ & $\begin{array}{c}\text { Galur } \mathrm{M}_{4} \mathrm{DR} \\
4.8 .8 \\
\text { DGU } 34.51^{*} \\
\text { Rata-rata } \\
250,00 \mathrm{~g}\end{array}$ & $\begin{array}{c}\text { Galur } \mathrm{M}_{4} \mathrm{DR} \\
3.1 .2 \\
\text { DGU 18.7.1* } \\
\text { Rata-rata } \\
290,67 \mathrm{~g}\end{array}$ \\
\hline 5 & & $\begin{array}{c}\text { Galur } \mathrm{M}_{4} \mathrm{BR} \\
\text { 153.2.2 } \\
\text { DGU 2.07* }^{*} \\
\text { Rata-rata } \\
\text { 20,03 mm }\end{array}$ & $\begin{array}{c}\text { Galur } \mathrm{M}_{4} \mathrm{DR} \\
\text { 18.3.1 } \\
\text { DGU 34.50* } \\
\text { Rata-rata } \\
225,00 \mathrm{~g}\end{array}$ & \\
\hline 6 & & & $\begin{array}{c}\text { Galur } \mathrm{M}_{4} \mathrm{DR} \\
10.2 .2 \\
\text { DGU } 31.71^{*} \\
\text { Rata-rata } \\
220,00 \mathrm{~g}\end{array}$ & \\
\hline \multicolumn{5}{|c|}{$\begin{array}{l}\text { Keterangan : PT = Panjang tongkol }(\mathrm{cm}) ; \mathrm{DT}=\text { Diameter tongkol } \\
(\mathrm{cm}) ; \mathrm{B} 1000=\text { Bobot } 1000 \mathrm{biji} ; \mathrm{BBT}=\text { Bobot biji per tanaman } \\
(\mathrm{g}) \text {. } \\
{ }^{*} \text { signifikan berdasarkan Uji t pada taraf } 5 \% \text {. }\end{array}$} \\
\hline
\end{tabular}




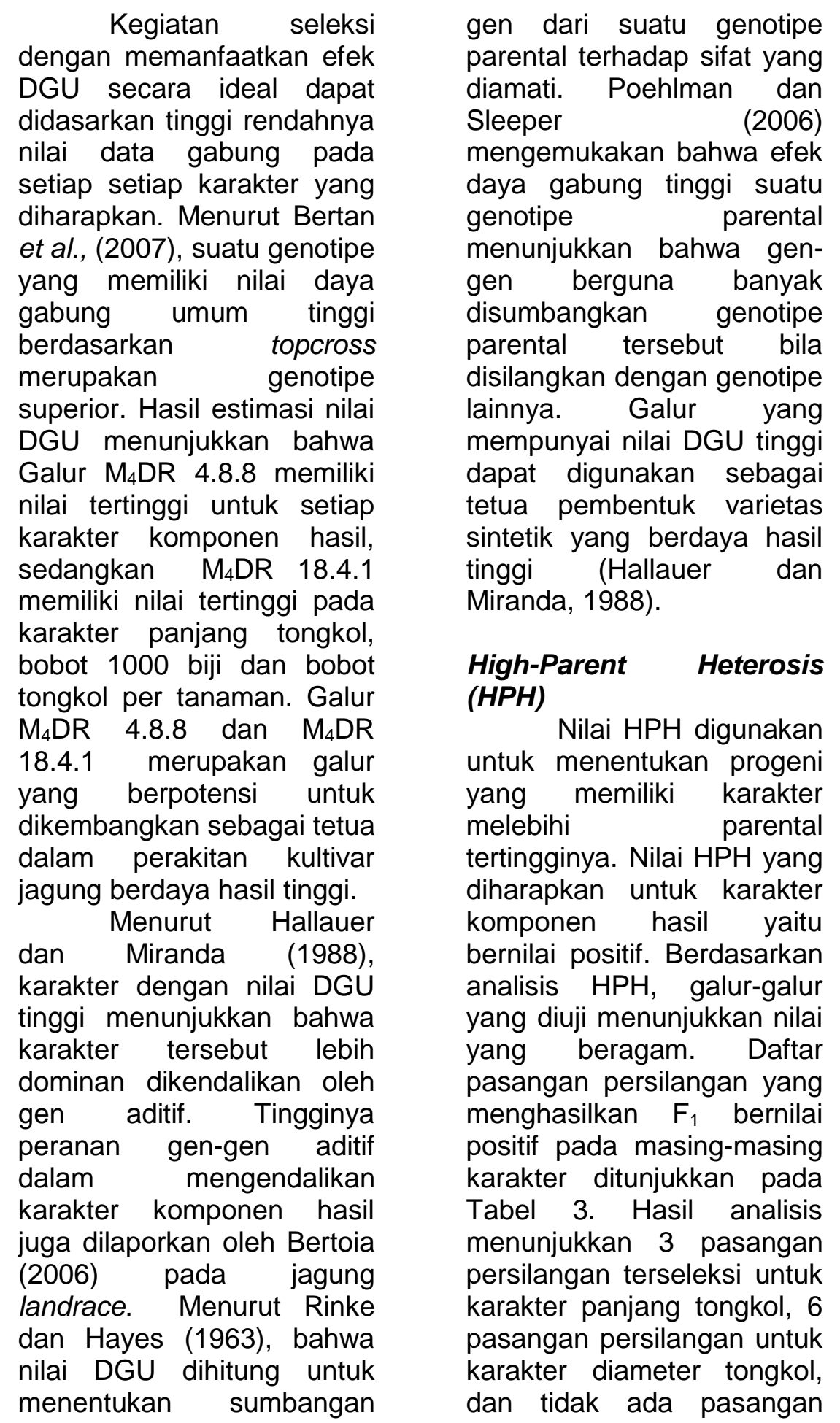


persilangan yang terseleksi untuk karakter Bobot biji
1000 dan bobot tongkol per tanaman.

Tabel 3. Pasangan persilangan terpilih berdasarkan nilai HPH $\mathrm{F}_{1}$ tertinggi pada beberapa karakter komponen hasil

\begin{tabular}{|c|c|c|c|c|}
\hline No. & PT & DT & B 1000 & BBT \\
\hline$\overline{11}$ & $\begin{array}{c}\mathrm{F} 1 \mathrm{M}_{4} \mathrm{DR} \\
5.5 .1 \times \mathrm{DR} 8 \\
\mathrm{HPH} \mathbf{2 5 , 7 1} \\
\%^{*}\end{array}$ & $\begin{array}{c}\text { F1 M4DR 1.6.3 } \\
\text { x DR8 } \\
\text { HPH 19,91 \%* }\end{array}$ & & \\
\hline 2 & $\begin{array}{c}\mathrm{F} 1 \mathrm{M}_{4} \mathrm{DR} \\
16.1 .1 \times \mathrm{DR} 8 \\
\mathbf{H P H} \mathbf{2 4 , 5 3} \\
\%^{*}\end{array}$ & $\begin{array}{c}\mathrm{F} 1 \mathrm{M}_{4} \mathrm{DR} \\
\text { 12.3.2 x DR8 } \\
\text { HPH } \mathbf{1 8 . 6 3} \%{ }^{*}\end{array}$ & & \\
\hline 3 & $\begin{array}{c}\mathrm{F} 1 \mathrm{M}_{4} \mathrm{DR} \\
12.3 .2 \times \mathrm{DR} 8 \\
\mathrm{HPH} 22,97 \\
\%^{*}\end{array}$ & $\begin{array}{c}\mathrm{F} 1 \mathrm{M}_{4} \mathrm{BR} \\
153.2 .2 \times \mathrm{DR} 8 \\
\text { HPH } \mathbf{1 8 , 2 0} \%{ }^{*}\end{array}$ & & \\
\hline 4 & & $\begin{array}{c}\mathrm{F} 1 \mathrm{M}_{4} \mathrm{DR} \\
\text { 14.3.8 x DR8 } \\
\text { HPH } \mathbf{1 6 , 9 0 \% *}\end{array}$ & & \\
\hline 5 & & $\begin{array}{c}\mathrm{F} 1 \mathrm{M}_{4} \mathrm{DR} \\
\text { 16.1.1 x DR8 } \\
\text { HPH } \mathbf{1 6 , 4} \% *\end{array}$ & & \\
\hline 6 & & $\begin{array}{c}\mathrm{F} 1 \mathrm{M}_{4} \mathrm{BR} \\
153.13 .1 \times \mathrm{DR} 8 \\
\text { HPH } \mathbf{1 4 , 4} \% *\end{array}$ & & \\
\hline
\end{tabular}

Keterangan : PT $=$ Panjang tongkol $(\mathrm{cm}) ; \mathrm{DT}=$ Diameter tongkol $(\mathrm{cm})$; B1000 = Bobot $1000 \mathrm{biji} ;$ BBT = Bobot biji per tanaman (g).

* signifikan berdasarkan Uji t pada taraf $5 \%$

Gejala heterosis mempunyai arti yang sangat penting dalam pembentukan varietas unggul baru. Nilai $\mathrm{HPH}$ yang tinggi dapat disebabkan karena parental yang digunakan memiliki keragaman yang tinggi juga memiliki jarak genetik yang jauh diantara tetua persilangan (Fehr, 1987 ;
Rief et al., 2005). Terdapat tiga teori yang melandasi terjadinya heterosis yaitu hipotesis dominant gene, Over dominant dan epistasisis. Teori yang cukup menonjol yang melandasi peristiwa heterosis ini adalah teori dominan. Salah satu penelitian yang 
menunjukkan fenomena tersebut diantaranya yaitu penelitian yang dilakukan oleh Li et al., (2008) mengenai analisis heterosis berdasarkan QTL pada dua heterotic group padi hibrida.

\section{KESIMPULAN}

1. Terseleksi 12 Galur berdasarkan analisis daya gabung pada karakter komponen hasil.

2. Terseleksi 7 pasangan persilangan berdasarkan nilai $\mathrm{HPH}$.

3. Galur M4DR 4.8.8 dan M4DR 18.4.1 merupakan Galur yang berpotensi untuk dikembangkan sebagai tetua dalam perakitan kultivar jagung berdaya hasil tinggi.

\section{DAFTAR PUSTAKA}

Allard, R. W. 1960. Principles of Plant Breeding. John Wiley and Sons, Inc. New York.

Beck, D.I., S.K. Vasal, J. Crossa. 1990. Heterosis and combining ability of CIMMYT'S tropical early and intermediate maturity maize germplasm. Maydica, 35: 279-285.

Bertan, I., F.I.F. Carvalho, A.C. de Oliveira. 2007. Parental Selection Strategies in Plant Breeding Programs.

$\begin{array}{lr}\text { Journal of } & \text { Crop } \\ \text { Science } & \text { and } \\ \text { Biotechnology. } & \text { Vol.10, } \\ \text { p.211-222. } & \end{array}$

Bertoia, L., C. Lopez, and R. Burak. 2006. Biplot Analysis of Forage Combining Ability in Maize Landraces. Crop Science. 46:13461353.

Doerksen, T. K., L. W. Kannenberg and E. A. Lee. 2003. Effect of recurrent selection on combining ability in maize breeding populations. In Crop Breeding, Genetics and Cytology. Crop Sci. Avaible on line at: http://www.cropscience .com. Diakses tanggal 1 Oktober 2017.

Fehr, W. R. 1987. Principle of Cultivar Development. Theory and Technique. Vol 1. Macmillan Publishing Company. New York.

Hallauer, A.R. and Miranda, F., J.B. 1988. Quantitative Genetics in Maize Breeding. lowa State University Press/Ames.

Li, L., K. Lu, Z. Chen, T. Mu, Z. Hu, and X. Li. 2008. Dominance,

Overdominance and Epistasis Condition the Heterosis in Two Heterotic Rice Hybrids. Genetics. Vol. 180(3): 1725-1742.

Poehlman, J, M, and D, A, Sleeper. 2006. 
Breeding Field Crops Fifth Edition, lowa State University Press, Ames, lowa 50014.

Rief, J.C., A.R. Hallaur, A.E. Melchinger, 2005. Heterosis and Heterotic Pattern in Maize. Maydica 50: 215-223

Rinke, E.H. and H.K. Hayes. 1963. General and combining ability in Diallel Crosses of 15 Inbred Lines of Corn. Botanical Bulletin of Academia Sinica, Vol. 5

Shull, G.H., 1908 The composition of a field of maize. Am. Breed. Assoc. Rep. 4: 296301.

Singh, H.K. and B.D. Chaudhary. 1979. Biometrical Methods in Quantitative Genetic Analysis. Kalyani Publisher. Ludhiana. New Delhi. P. 191-200.

Sucipto, I.A., A. Ismail, D.Ruswandi,2013.

Kekerabatan jagung mutan dan galur elit Unpad sebagai plasma nutfah jagung semi. Prosiding Seminar Nasional Perhimpunan Hortikultura Indonesia 2013.

Sprague, G.F. and Tatum, L.A. (1942). General vs specific combining ability in single crosses of corn. J. American Soc. Agron., 34: 923932.
Vasal, S.K., G. Srinivasan, H. Cordova, S. Pandey, D. Jeffers, D. Bergvinson, D. Beck. 1999. Inbred Line Evaluation Nurseries and Their Role in Mauze Breeding at CIMMYT. Maydica, 44: 341-35 
Lampiran 1 Nilai daya gabung umum (DGU) dan high-parent heterosis (HPH) dari masing-masing genotipe berdasarkan karakter komponen hasil

\begin{tabular}{|c|c|c|c|c|c|c|c|c|c|c|c|c|c|c|}
\hline \multirow{3}{*}{$\begin{array}{c}\text { Galur } \\
M_{4} \text { DR 1.1.3 }\end{array}$} & \multicolumn{4}{|c|}{ PT } & \multicolumn{4}{|c|}{ DT } & \multicolumn{3}{|c|}{ W1000 } & \multicolumn{3}{|c|}{ BBT } \\
\hline & \multicolumn{2}{|c|}{ DGU } & \multicolumn{2}{|l|}{ HPH } & \multicolumn{2}{|c|}{ DGU } & \multicolumn{2}{|c|}{ HPH } & \multicolumn{2}{|l|}{ DGU } & \multirow{2}{*}{\begin{tabular}{|c|} 
HPH \\
-11.7
\end{tabular}} & \multirow{2}{*}{$\begin{array}{l}\text { DGU } \\
-3.4\end{array}$} & \multirow{2}{*}{\multicolumn{2}{|c|}{$\begin{array}{l}\mathbf{H P H} \\
-11\end{array}$}} \\
\hline & -0.02 & & -0.36 & & 2.13 & * & 2.34 & & 0 & & & & & \\
\hline$M_{4}$ DR 1.2 .3 & 0.65 & & 13.3 & & -0.25 & & 6.56 & & 11.11 & & -8.96 & 4.1 & & -0.8 \\
\hline$M_{4}$ DR 1.2.12 & 0.73 & & -1.38 & & 0.03 & & 3.17 & & 2.85 & & -7.57 & -3.73 & & 13.3 \\
\hline$M_{4}$ DR 1.6.3 & -0.48 & & 16.8 & & 1.3 & & 19.9 & $\star *$ & -3.27 & & -20.7 & 4.27 & & 16.8 \\
\hline $\mathrm{M}_{4}$ DR 3.1.2 & 0.73 & & -1.78 & & 1.55 & & 6.23 & & 59.5 & $* *$ & 21.4 & 18.71 & * & 21.7 \\
\hline$M_{4}$ DR 3.1.4 & 1.15 & & -5.84 & & -0.52 & & -3.4 & & -9.39 & & -22.8 & 8.99 & & -9.6 \\
\hline$M_{4}$ DR 3.6.1 & -0.16 & & 13.3 & & 0.39 & & 2.92 & & -5.49 & & -4 & 6.27 & & 26.8 \\
\hline$M_{4}$ DR 3.6.2 & -0.5 & & -2.95 & & -1.39 & & -3 & & -28.84 & & -17.9 & -3.79 & & -9.3 \\
\hline$M_{4}$ DR 4.1.3 & -1.39 & * & -0.45 & & -1.56 & & 12.6 & & -7.15 & & -6.21 & -23.62 & * & -6.1 \\
\hline$M_{4}$ DR 4.8 .8 & 1.83 & ** & 7.28 & & 2.28 & * & 5.28 & & 34.51 & * & 3.46 & 21.93 & * & 36.4 \\
\hline$M_{4}$ DR 5.5.1 & 1.84 & ** & 25.7 & * & 0.15 & & 8.35 & & 21.18 & & 0.02 & 4.82 & & 16.2 \\
\hline$M_{4}$ DR 7.1.2 & -0.04 & & 11.4 & & -0.79 & & 1.31 & & -26.7 & & -32.4 & -0.56 & & 8.22 \\
\hline $\mathrm{M}_{4}$ DR 7.1.9 & 1.02 & & 11.7 & & -0.1 & & -2.6 & & -2.15 & & -17.9 & 6.71 & & 10.3 \\
\hline$M_{4}$ DR 7.3.1 & 0.58 & & 5.71 & & -2.37 & * & -4.9 & & -13.82 & & -13.1 & -0.9 & & 5.48 \\
\hline $\mathrm{M}_{4}$ DR 7.3.2 & -2.44 & ** & 1.71 & & -3.27 & ** & 3.36 & & -38.84 & * & -31 & -29.51 & $* *$ & -27 \\
\hline$M_{4}$ DR 7.4.1 & 0.82 & & 1.35 & & -0.84 & & 1.1 & & 11.2 & & -17.4 & 1.1 & & -8.8 \\
\hline
\end{tabular}




\begin{tabular}{|c|c|c|c|c|c|c|c|c|c|c|c|c|c|c|c|}
\hline \multirow{3}{*}{$\begin{array}{c}\text { Galur } \\
\mathrm{M}_{4} \text { DR 7.4.2 }\end{array}$} & \multicolumn{4}{|c|}{ PT } & \multicolumn{4}{|c|}{ DT } & \multicolumn{4}{|c|}{ W1000 } & \multicolumn{3}{|c|}{ BBT } \\
\hline & \multicolumn{2}{|c|}{ DGU } & \multicolumn{2}{|l|}{ HPH } & \multicolumn{2}{|c|}{ DGU } & \multicolumn{2}{|c|}{ HPH } & \multicolumn{2}{|c|}{ DGU } & \multicolumn{2}{|c|}{$\mathrm{HPH}$} & \multirow{2}{*}{$\begin{array}{c}\text { DGU } \\
1.93\end{array}$} & \multirow{2}{*}{\multicolumn{2}{|c|}{$\begin{array}{l}\text { HPH } \\
-26\end{array}$}} \\
\hline & -0.04 & & -1.49 & & 1.36 & & 3.37 & & -7.7 & & -42.8 & $\star *$ & & & \\
\hline$M_{4}$ DR 8.5 .2 & 1.71 & * & 9.81 & & 0.22 & & 0 & & -7.7 & & -40 & * & 4.71 & & 1.55 \\
\hline$M_{4}$ DR 8.5.3 & -0.18 & & 9.8 & & -1.42 & & 5.77 & & -44.92 & $* *$ & -31 & & -13.96 & & 2.1 \\
\hline$M_{4}$ DR 8.6.3 & -0.84 & & 10.8 & & 0.48 & & 9.93 & & -1.6 & & -11 & & 2.93 & & 12.8 \\
\hline$M_{4}$ DR 8.8 .1 & -0.02 & & -2.53 & & -2.72 & $* *$ & -7.2 & & -17.15 & & -45.8 & $* *$ & -10.01 & & -21 \\
\hline$M_{4}$ DR 9.1.3 & 0.94 & & 2.81 & & 1.69 & & -0.9 & & 5.63 & & -22.9 & & 20.38 & * & 10.5 \\
\hline$M_{4}$ DR 9.1 .5 & -0.53 & & -13.8 & & -1.45 & & -1.5 & & -11.04 & & -40 & $*$ & -16.9 & & -14 \\
\hline$M_{4}$ DR 9.4.1 & -0.88 & & -4.27 & & -2.52 & $* *$ & 2.02 & & -28.32 & & -51.7 & $* *$ & -14.68 & & -2.1 \\
\hline$M_{4}$ DR 10.2 .2 & 0.44 & & 17.8 & & 1.25 & & 12.6 & & 31.71 & * & 4.82 & & 5.83 & & 22.7 \\
\hline$M_{4}$ DR 10.2 .9 & -0.53 & & 9.11 & & -0.58 & & 5.68 & & -16.59 & & -14.5 & & -11.29 & & 17.4 \\
\hline$M_{4}$ DR 12.3 .1 & -0.94 & & 5.35 & & -0.15 & & 2.31 & & -42.15 & $* *$ & -34.5 & & -3.9 & & -0.4 \\
\hline$M_{4}$ DR 12.3 .2 & 0.6 & & 23 & * & 3.27 & ** & 18.6 & $* *$ & 25.06 & & -0.68 & & 13.32 & & 33.7 \\
\hline$M_{4}$ DR 14.1.1 & 0.27 & & 8.79 & & 1.64 & & 12.7 & & 10.63 & & -22.7 & & 6.77 & & 16 \\
\hline$M_{4}$ DR 14.2 .2 & -1.74 & ** & -5.26 & & -0.2 & & -0.7 & & -42.14 & $* *$ & -38.8 & * & -15.9 & & -19 \\
\hline$M_{4}$ DR 14.3.1 & 0.6 & & -1.9 & & -1.47 & & 5.22 & & -34.94 & * & -33.7 & * & -0.51 & & -23 \\
\hline$M_{4}$ DR 14.3.8 & -0.08 & & 0.38 & & 1.14 & & 16.9 & ** & -7.7 & & -8.16 & & 4.38 & & 37.9 \\
\hline$M_{4}$ DR 16.1.1 & 0.22 & & 24.5 & * & 5.07 & $* *$ & 16.4 & $* *$ & 45.63 & $* *$ & 24.2 & & 17.93 & & 36.7 \\
\hline$M_{4}$ DR 16.2 .1 & 0.47 & & -14 & & 0.92 & & -10 & & 17.85 & & -17.9 & & 4.38 & & -42 \\
\hline$M_{4}$ DR 18.2.1 & -0.68 & & -7.26 & & -1.33 & & -1.3 & & 21.18 & & 3.46 & & -16.79 & & -36 \\
\hline
\end{tabular}




\begin{tabular}{|c|c|c|c|c|c|c|c|c|c|c|c|c|c|c|}
\hline \multirow{3}{*}{$\begin{array}{c}\text { Galur } \\
\mathrm{M}_{4} \text { DR 18.3.1 }\end{array}$} & \multicolumn{3}{|c|}{ PT } & \multicolumn{4}{|c|}{ DT } & \multicolumn{4}{|c|}{ W1000 } & \multicolumn{3}{|c|}{ BBT } \\
\hline & \multicolumn{2}{|l|}{ DGU } & \multirow{2}{*}{$\frac{\text { HPH }}{8}$} & \multicolumn{2}{|c|}{ DGU } & \multicolumn{2}{|c|}{ HPH } & \multicolumn{2}{|l|}{ DGU } & \multicolumn{2}{|l|}{ HPH } & \multicolumn{2}{|c|}{ DGU } & \multirow{2}{*}{$\begin{array}{c}\mathbf{H P H} \\
12.5\end{array}$} \\
\hline & -0.74 & & & 0.9 & & 10.1 & & 34.5 & * & -28.9 & * & 5.77 & & \\
\hline $\mathrm{M}_{4}$ DR 18.4.1 & 2.3 & $* *$ & 14.9 & 1.7 & & 6.95 & & 40.06 & * & -18.5 & & 30.43 & $* *$ & 41.5 \\
\hline$M_{4}$ DR 18.8.1 & 0.14 & & 1.4 & -1.14 & & 6.25 & & -7.7 & & -27.3 & & 1.27 & & -11 \\
\hline$M_{4}$ BR 153.1.2 & -0.25 & & 2.26 & 0.29 & & 2.86 & & 17.3 & & -31 & & 9.49 & & -14 \\
\hline$M_{4}$ BR 153.2 .2 & -0.27 & & -2.9 & 2.07 & * & 18.2 & ** & -2.14 & & -17.2 & & 7.6 & & 7.37 \\
\hline $\mathrm{M}_{4} \mathrm{BR}$ 153.3.2 & -0.27 & & -8.58 & -1.92 & * & -7.1 & & -11.05 & & -38.9 & * & -9.9 & & -29 \\
\hline$M_{4}$ BR 153.4.1 & -0.87 & & 15.5 & -0.61 & & 1.38 & & -12.17 & & -31.7 & & -20.73 & * & -12 \\
\hline$M_{4}$ BR 153.6.1 & -0.24 & & 11.7 & -2.83 & $* *$ & -1.3 & & -0.49 & & -18.8 & & -5.57 & & -18 \\
\hline$M_{4}$ BR 153.7.1 & -0.23 & & -14.4 & -0.21 & & -4.2 & & 30.06 & & -20.7 & & -0.34 & & -18 \\
\hline$M_{4}$ BR 153.10 .2 & -0.37 & & 6.28 & 0.06 & & 4.5 & & 11.2 & & -6.89 & & -3.07 & & -13 \\
\hline $\mathrm{M}_{4}$ BR 153.13.1 & -1.1 & & -1.95 & -0.22 & & 14.4 & * & 0.06 & & -20.7 & & -4.96 & & -2.1 \\
\hline DR8 & 0.17 & & & 0.99 & $* *$ & & & 6.87 & & & & 5.67 & * & \\
\hline
\end{tabular}

Keterangan : PT $=$ Panjang tongkol $(\mathrm{cm}) ; \mathrm{DT}=$ Diameter tongkol $(\mathrm{cm}) ; \mathrm{B} 1000=$ Bobot 1000 biji $; \mathrm{BBT}=$ Bobot biji per tanaman $(\mathrm{g})$.

* signifikan berdasarkan Uji t pada taraf $5 \%$ 